\title{
Prinsip Piercing The Corporate Veil Pada Perseroan Terbatas Sebagai Badan Hukum
}

\author{
Ananda Rizky Suharto \\ Fakultas Hukum, Universitas 17 Agustus 1945 Surabaya, Jl. Semolowaru 45, Surabaya, 60118 \\ E-mail: anandarizkysuhartoo@gmail.com
}

\begin{abstract}
The principle of piercing the corporate veil simply can make the form of accountability of shareholders, directors and commissioners of the company in certain matters unlimited. The research aims to analyze the existence of the principle of piercing the corporate veil of limited liability companies and its regulation in Law Number 40 of 2007 concerning Limited Liability Companies. Using normative legal research that is legal research that focuses on the study of positive law. This study offers an explanation of the application of the principle of piercing the corporate veil based on Law Number 40 of 2007 concerning Limited Liability Companies (UUPT) related to shareholder liability for company losses. In the development of business law in Indonesia, the principle of limited liability of the company's shareholders remains unwavering. the company as a legal entity is no different from humans. The Company as a legal entity is a legal subject that legally holds rights and obligations. Based on the perspective of legal subjects of business entities it is known that the company is a legal subject that can be processed by applicable law. The Company Law as a national law regulation can be used as a legal umbrella for the company. The use as a legal umbrella is adjusted to the level, degree, and regulation of the law itself related to the binding capacity of the material contained in the rule of law. This is called the concept of justice and legality. The concept of justice and legality is applied through Law Number 40 of 2007 concerning Limited Liability Companies as the application of the principle of piercing the corporate veil to companies in Indonesia.
\end{abstract}

Keywords - : piercing the corporate veil; company; shareholder.

\section{PENDahuluan}

Perseroan merupakan kesatuan hukum (legal entity) yang terpisah dari pemegang saham perseroan terbatas itu. Sebagai suatu kesatuan hukum (legal entity) yang terpisah dari pemegang sahamnya, perseroan dalam melakukan fungsi hukumnya bukan bertindak sebagai kuasa dari para pemegang sahamnya, tetapi bertindak untuk dan atas nama dirinya sendiri. Ciri utama suatu badan hukum adalah adanya pemisahan antara harta kekayaan badan hukum dan pribadi para pemegang saham. Para pemegang saham tidak bertanggung jawab secara pribadi atas perikatan yang dibuat atas nama badan hukum dan juga tidak bertanggung jawab atas kerugian badan hukum melebihi nilai saham yang telah dimasukkannya. Perseroan Terbatas mempunyai ciri utama yaitu Perseroan Terbatas merupakan subjek hukum yang berstatus badan hukum, yang pada gilirannya membawa tanggung jawab terbatas (limited liability) bagi para pemegang saham, yaitu sebesar saham yang dimasukkanya ke dalam Perseroan tersebut.

Pada perkembangan hukum bisnis di Indonesia, prinsip pertanggungjawaban terbatas para pemegang saham tetap kuat tidak tergoyahkan. "Pada umumnya gugatan ditujukan pada direksi atau pemegang saham pengendali, dan pengadilan merobek cadarperseroan, atas dasar bahwa perseroan tersebut hanya digunakan sebagai topeng atau agen dari pemegang saham". ${ }^{1}$ Penyingkapan atau merobek cadar perseroan ini (piercing the corporateveil) pengadilan memperhatikan substansi atau kenyataan praktis pada bentuk formal dari perseroan terbatas tersebut. Pengadilan menyingkap tabir perseroan jika pemegang saham dengan sengaja atau sebaliknya mempergunakan perseroan sebagai alat untuk memperoleh keuntungan tertentu atau untuk menghindari kewajiban-kewajiban hukum. Terkaitkemungkinan adanya penyalahgunaan bentuk perseroan, pengadilan dapat menganggap perseroan semata-mata sebagai selubung (cloak) atau kepura-puraan (sham) dan pengadilan akan menyingkap tabir perseroan. ${ }^{2}$ Sehingga berdasarkan prinsip penyingkapan tirai perusahaan (piercing the corporate veil), pertanggungjawaban secara hukum dapat dibebankan kepada para pengurusnya. Penelitian ini menawarkan penjelasan bentuk penerapan prinsip piercing the corporate veil berdasarkan Undang undang Nomor 40 Tahun 2007 tentang Perseroan Terbatas (UUPT) terkait pertanggungjawaban pemegang saham atas kerugian perseroan.

Perbandingan penelitian pertama menhasilkan jawaban bahwa berkaitan dengan prinsip piercing the corporate veil, perbuatan melawan hukum yang dilakukan oleh pemegang saham dalam perseroan dapat terjadi dikarenakan untuk mencapai kepentingan pribadi pemegang saham melaluai pemanfaatan fasilitas yang ada dengan memanipulasi perbuatan hukum atau pengelolaan kekayaan perseroan. Perihal ini dimungkinkan ketika perseroan bertindak tidak atas dan demi kepentingannya

${ }^{1}$ Ais Chatamarrasjid, Penerobosan Cadar Perseroan dan Soal-soal Aktual Hukum Perusahaan, Citra Aditya Bakti, Bandung, 2004, h. 1.

${ }^{2}$ Ibid. 
sendiri, tapi demi kepentingan para pemegang saham (alter ego) sehingga penyalahgunaan terhadap pereroan sangat mungkin terjadi. Di sisi lain, pada Undang-undang Nomor 8 Tahun 2010 tentang Pencegahan dan Pemberantasan Tidnak Pidana Pencucian Uang (UUTPPU) menyatakan bahwa berkaitan dengan prinsip piercing the corporate veil dalam perbuatan melawan hukum yang dilakukan oleh pemegang saham dapat terjadi karena pemegang saham melakukan perbuatan melawan hukum san memanfaaatkan fasilitas yang ada untuk kepentingan pribadinya dengan cara memanipulasi perbuatan hukum ataupun pengelolaan kekayaan perseroan. Terkait tindak pidana pencucian uang, prinsip piercing the corporate veil dalam UUTPPU menyatakan bahwa pemegang saham selaku anggota korporasi dapat dimintakan pertanggungjawaban sampai pada harta pribadinya. Perihal ini dakarenakan kapasitas pemegang saham sebagai pihak yang mempunyai kekuasaan atau wewenang yang menentukan kebijakan korporasi atau wewenang untuk melakukan kebijakan korporasi tanpa harus mendapat otorisasi dari atasannya. Berdasarkan UUTPPU menyarakan bahwa perseroan terkait harus terlebih dahulu diputuskan tidak mampu membayar denda, sehingga pemegang saham selaku anggota korporasi dapat dimintakan pertanggungjawaban baik berupa perampasan harta kekayaan (pidana denda) atau pidana kurungan. Penerapan prinsip piercing the corporate veil mewajibkan adanya tindakan pemidanaan terhadap korporasi terlabih dahulu demi mengejar pemidanaan terhadap pemegang saham selaku anggota pengendali korporasi yang dapat menimbulkan kerugian bagi pemegang saham lainnya yang beritikad baik. ${ }^{3}$

Penelitian kedua menyimpulkan bahwa argumentasi diberlakukannya prinsip piercing the corporate veil terhadap perusahaan induk yang berhubungan dengan tindakan hukum anak perusahaan yaitu, terjadinya domunasi tanpa tanggung jawab yang dilakukan perusahaan induk kepada anak perusahaan, perusahaan induk berlindung dibalik tirai pertanggungjawaban terbatas, adanya tindakan melawan hukum atau kesalahan dari perusahaan induk, dan karena adanya unsur kerugian terhadap pihak ketiga. Berdasarkan pada teori subjek hukum yang menyebutkan bahwa subjek hukum mempunyai hak dan kewajiban serta sebuah perseroan terbatas mempunyai kedudukan sebagai badan sebagai hukum sendiri yang terpisah. Di sisi lain, ketika secara ekonomu antara perusahaan induk dan anak perusahaan mempunyai hubungan maka perusahaan induk memiliki kewajiban untuk bertanggung jawab terhadap anak perusahaan ketika terjadi kerugian. Pada teori badan hukum dijelaskan bahwa terdapat pemisahan harta kekayaan antara perusahaan induk dan anak perusahaan maka perusahaan induk bertanggung jawab terhadap tindakan hukum anak perusahaan sebatas saham yang ditanamkan dan tidak akan melebihi saham tersebut yang mengartikan bahwa kondisi ini normal. Lebih lanjut, ketika tanggung jawab perusahaan induk menjadi tidak terbatas maka inilah wujud penerapan prinsip piercing the corporate veil. Perihal ini membuat tanggung jawab perusahaan induk dapat melebihi saham yang ditanamkannya sesuai dengan ketentuan-ketentuan yang telah diatur. Salah satunya adalah mengganti rugi melebihi saham yang ditanamkan sesuai dengan kerugian yang dialami jika tindakan hukum perusahaan anak merupakan hasil dari intervensi perusahaan induk. Hukuman ganti rugi yang dimaksud merupakan ganti rugi sesuai yng dialami oleh si perugi dan bisa akan lebih tentunya dengan melihat objek kerugiannya. Besarnya jumlah ganti rugi tersebut tesebut dimaksudkan sebagai hukuman bagi si pelaku yang dalam hal ini adalah perusahaan induk sebagai pelaku realitas bisnis terhadap tindakan hukum anak perusahaannya. ${ }^{4}$

Berdasarkan jumlah penelitian yang mempunyai tema relevan dengan penelitian ini maka pada penelitian ini dirumuskan dua rumusan masalah, yaitu terkait keberadaan prinsippiercing the corporate veil pada Perseroan Terbatas dan pengaturanprinsippiercing the corporate veil pada Undang-Undang Nomor 40 Tahun 2007 tentang Perseroan Terbatas.

\section{METODE}

Penelitian ini menggunakan penelitian hukum normatif yaitu penelitian hukum yang menitik beratkan pada telaah hukum positif. Terkait proses penelitian hukum, Peter Mahmud Marzuki menyatakan bahwa penelitian hukum adalah salah satu proses untuk menemukan aturan hukum, prinsip-prinsip atau prinsip-prinsip hukum untuk menghasilkan suatu argumentasi. Argumentasi tersebut pada waktunya dapat digunakan dalam menyelesaikan berbagai permasalahan atau isu hukum yang dihadapi.

\section{III.HASIL PENELITIAN DAN PEMBAHASAN}

\section{A. Prinsip Piercing The Corporate Veil pada Perseroan Terbatas}

\section{Organ Perseroan Terbatas}

Undang-undang Nomor Tahun 2007 tentang Perseroan Terbatas (selanjutnya disingkat dengan UUPT), dibentuk dalam era globalisasi. Perihal menjadikan terdapatnya berbagai prinsip hukum yang mempengaruhi isi dari UUPT tersebut, termasuk prinsip hukum dari negara Common Law System. Tri Widodo berpendapat bahwa badan hukum sebagai subyek hukum berhubungan dengan subyek hukum lainnya, maka apabila terjadi dispute, tuntutan hukum dapat dialamatkan kepada badan hukum lainnya. Sekalipun dalam bertindak badan hukum tersebut diwakili oleh

\footnotetext{
${ }^{3}$ Benny Batara Tumpal Hutabarat, Penerapan Prinsip Piercing The Corporate Veil Terhadap Pemegang Saham Selaku Personil Pengendali Korporasi Dalam Tindak Pidana Pencucian Uang Oleh Perseroan Terbatas, Universitas Indonesia, Depok, 2011, h. 9.

${ }^{4}$ Muhammad Syafi'i, Piercing The Corporate Veil Terhadap Holding Company Dalam Tindakan Hukum Anak Perusahaan, Universitas Muhammadiyah, Yogyakarta, h. 1-10.

${ }^{5}$ Peter Mahmud Marzuki, Penelitian Hukum, Kencana Prenada Media Group, Jakarta, 2016, h. 135.
} 
direksinya, tetapi hubungan hukum tersebut tetap merupakan salah satu organ perseroan dari badan hukum itu mempunyai hubungan dan tanggung jawab intern perseroan. ${ }^{6}$

Hubungan hukum intern perseroan ini maksudnya adalah hubungan hukum antara pemegang saham, RUPS, Komisaris dan Direksi. Secara intern, perseroan terbatas sebagai badan hukum mempunyai hubungan hukum yang tercipta berdasarkan hal-hal sebagai berikut: ${ }^{7}$

a) Peraturan perundang-undangan yang berlaku

b) Anggaran dasar perseroan

c) Prinsip hukum yang berlaku umum dan universal.

Hubungan hukum intern tersebut membatasi kesewenang-wenangan pemegang saham, direksi, dan komisaris yang sekaligus meletakkan tanggung jawab masing-masing. Hal-hal tersebut di atas memberikan arah apa yang diperintahkan (imperare), apa yang dilarang (prohibere), serta apa yang diperbolehkan (permittere) kepada pemegang saham, komisaris, dan direksi. ${ }^{8}$

Sebagai "artificial person", perseroan tidak mungkin dapat bertindak sendiri. Perseroan tidak memiliki kehendak untuk menjalankan dirinya sendiri. Oleh karena itu diperlukan orang-orang yang memiliki kehendak yang akan menjalankan perseroan tersebut sesuai dengan maksud dan tujuan pendirian perseroan. Orang-orang yang akan menjalankan, mengelola, dan mengurus perseroan ini, dalam Undang-Undang Perseroan Terbatas disebut dengan istilah "organ perseroan". Masing-masing organ dalam perseroan memiliki tugas dan wewenang yang berbeda-beda dalam melakukan pengelolaan dan pengurusan perseroan. ${ }^{9}$ Pada perseroan terbatas terdapat 3 (tiga) organ yaitu, Rapat Umum Pemegang Saham (RUPS), Direksi, dan Komisaris. Rapat Umum Pemegang Saham (algemene vergardering van aandeelhourders) adalah lembaga yang mewadahi para pemegang saham (stoekholder, aandeelhourder) dan merupakan organ perseroan pemegang kekuasaan tertinggi serta memegang kewenangan yang tidak diserahkan kepada Direksi dan Komisaris. ${ }^{10}$ Direksi (Board of Direktor) merupakan organ perseroan yang bertanggung jawab penuh atas pengurusan perseroan (fiduciary duty), mewakili perseroan baik di dalam, maupun di luar pengadilan berdasarkan Anggaran Dasar (intra vires). ${ }^{11}$ Komisaris sebagai salah satu organ perseroan mempunyai tugas melakukan pengawasan secara umum atau khusus dan memberikan nasihat kepada direksi dalam menjalankan sebuah perseroan. ${ }^{12}$

2. Pertanggungjawaban Terbatas Pengurus Perseroan

Perseroan dan pemegang saham adalah pihak yang terpisah. Walaupun para pemegang saham adalah pemilik perseroan, mereka tidak dapat dituntut untuk melunasi hutang-hutang milik perseroan. Perihal ini dikarenakan antara pihak perseroan dan pemegang saham telah mengadakan perjanjian. Perjanjian yang menyatakan masing-masing pihak telah memisahkan sebagian harta kekayaan milik pribadi dari harta kekayaan perseroran. Begitupun sebaliknya, harta kekayaan perseroan juga dipisahkan dari harta kekayaan pribadi milik pemegang saham. Pemisahan harta pribadi milik pemegang saham dan perseroan mengartikan bentuk pertanggungjawaban pemegang saham hanya sebatas pada harta kekayaan milik pribadinya yang diinvestasikan pada perseroan terkait.

Lebih lanjut, pemegang saham tidak mempunyai kewajiban dalam melunasi hutang-hutang perseroan. Hal ini terjadi jika hasil penjualan kekayaan perseroan tidak cukup untuk melunasi hutang-hutangnya. Demikian juga ketika harta kekayaan perseroan tidak cukup untuk melunasi hutangnya, pihak ketiga tidak bisa menuntut para pemegang saham agar melunasi hutang tersebut menggunakan harta pribadinya. Perihal ini dikenal dalam istilah hukum sebagai doktrin keterbatasan tanggung jawab. Doktrin tersebut secara prinsip mengartikan bahwa setiap perbuatan hukum yang dilakukan oleh suatu badan hukum merupakan tanggung jawab oleh badan hukum terkait dan para pemegang saham tidak diwajibkan bertanggung jawab diluar batas saham yang diinvestasikannya pada badan hukum terkait. ${ }^{13}$

Penjelasan di atas menunjukan bahwa harta kekayaan pribadi pemegang saham tidak turut serta dipertanggungjawabkan sebagai tanggungan perikatan yang dilakukan oleh badan hukum terkait. Rahmadi Usman sekali lagi berpendapat bahwa pemegang saham tidak bertanggung jawab secara pribadi atas perikatan yang dibuat atas nama badan hukum serta tidak bertanggungjawab atas kerugian badan hukum melebihi nilai sahan yang telah diinvestasikan. Pernyataan Rusmadi Usman tersebut dinamakan dengan prinsip "the doctrine of separate legal personality of a company" atau "the principle of company's separate legal personality". Prinsip tersebut dapat disingkat menjadi "doctrine of separate corporate personality". 14

\footnotetext{
${ }^{6}$ Tri Widiyono, Direksi Perseroan Terbatas (Bank Perseroan) Keberadaan, Tugas, Wewenang dan Tanggung Jawab, Berdasarkan Doktrin Hukum dan UUPT. Ghalia Indonesia, Jakarta, 2005, hal 29.

${ }^{7}$ Ibid., hal 7

${ }^{8}$ Ibid., hal 29

${ }^{9}$ Gunawan Widjaja, Tanggung Jawab Direksi atas Kepailitan Perseroan, Raja Grafindo Persada, Jakarta, 2004, hal 20.

${ }^{10}$ Umar Kasim, Tanggung Jawab Korporasi Dalam Hal Mengalami Kerugian, Kepailitan atau Likuidasi, Jurnal Informasi Hukum Vol. 2 Tahun 2005, diakses .dari http://www.nakertrans.go.id/majalah_buletin/info_hukum/vol2viio05/TanggungjawabKorporasi.php, dipetik 29 Maret 2020.

${ }^{11}$ Tri Widiyono. Op. Cit., h. 30.

${ }^{12}$ I.G. Ray Widjaja. Op. Cit., h. 25.

${ }^{13}$ Ibid., h. 149.

${ }^{14}$ Ibid.
} 
Bentuk pertanggungjawaban terbatas para pemegang saham pada awalnya menjadi sebuah kontroversi. Kontroversi muncul ketika beberapa ahli hukum dan praktisi bisnis mempunyai pandangan bahwa prinsip pertanggungjawaban terbatas pada pemegang saham mempunyai sifat yang absolute atau mutlak. Sifat mutlak ini mempunyai arti bahwa para pemegang saham hanya bertanggung jawab sebatas jumlah saham yang dimilikinya dan berlaku pada semua kondisi perseroan. Pendapat ini menimbulkan kontroversi berdasarkan pertimbangan bahwa jika pertanggungjawaban terbatas para pemegang saham bersifat mutlak, maka perseroan terbatas pada dasarnya hanya sebuah kedok usaha yang digunakan oleh para pemegang saham. Kedok tersebut digunakan oleh pemegang saham sebagau upaya untuk menghindari resiko kerugian yang dapat ditimbulkan sebagai akibat keterlibatannya dalam perseroan.

3. Kewenangan dan Tanggung Jawab Direksi

Rapat Umum Pemegang Saham (RUPS) menetapkan pembagian wewenang dan tugas (tanggung jawab) semua anggota direksi perseroan.

a) Kewenangan Direksi

Direksi dalam melaksanakan tugas dan kewenangannya berlandaskan pada tugas dan kedudukan yang didapatkan atas dasar dua prinsip. Dua prinsip tersebut adalah kepercayaan yang diberikan perseroan terhadapnya (fiduciary duty) dan kemampuan sekaligus sikap berhati-hati dalam setiap tindakan direksi (duty of skill and care). ${ }^{15}$ Berdasarkan kedua prinsip ini menuntut direksi agar bertindak selalu dengan itikad baik dan hati-hati. Perihal tersebut dimaksudkan untuk kepentingan dan tujuan perseroan terkait. Ketika direksi melanggar kedua prinsip ini akan mendapatkan konsekuensi hukum berat, yaitu dapat dituntut bertanggung jawab secara pribadi atas segala kerugian yang ditimbulkan kepada perseroan. Terpenuhi atau tidaknya kewenangan yang dimiliki oleh pihak pelaku menjadi landasan untuk dilakukanya suatu perbuatan hukum sebagai bentuk respon.

Kewenangan direksi termasuk dalam suatu kewenagnan yang berdasarkan: ${ }^{16}$

1) Kapasitas sebagai pemegang kuasa yang bertindak demi tujuan dan mengatas namakan pemberi kuasa.

2) Kapasitas diri sendiri sebagai seorang individu secara pribadi.

3) Kapasitas dalam bertindak atas jabatan terkait tindakan selaku yang berwenang berdasarkan jabatan yang dimiliki.

Konsep kewenangan dalam bertindak menjadi penting ketika dihubungkan pada konsekuensi hukum atas tidak terpenuhinya syarat subjektif sahnya suatu perjanjian. Ketika suatu perbuatan hukum tidak memenuhi syarat subjektif tersebut, terdapat hukum perjanjian dan peraturan perundang-undangan pada umumnya yang siap untuk mengancam. Ancaman yang ditimbulkan merupakan kebatalan atau dapat dibatalkannya sebuah perjanjian setiap saat dengan catatan selama masa kadaluarsa belum terlewati atau perjanjian terkait tidak diratifikasi lebih lanjut. Sesuai pada Kitab Undang-Undang Perdata Pasal 1331 yang menyatakan bahwa hak untuk membatalkan perjanjian diberikan kepada mereka yang syarat subjektifnya tidak terpenuhi. ${ }^{17}$

b) Batasan Kewenangan Direksi

Undang-Undang Nomor 40 Tahun 2007 tentang Perseroan Terbatas telah mengatur batasan-batasan kewenangan direksi di Indonesia. Ketentuan terkait batasan kewenangan direksi dalam perseroan sesuai UUPT tertuang pada Pasal 2, Pasal 92 ayat (1), Pasal 97 ayat (1), dan Pasal 102. Perihal pasal-pasal tersebut diuraikan di bawah ini. ${ }^{18}$

1) Pasal 2 UUPT menyatakan bahwa segala tindakan direksi diharuskan memiliki maksud dan tujuan usaha yang tidak bertentangan dengan peraturan perundang-undangan, ketertiban umum, dan kesusilaan.

2) Pasal 92 ayat (1) UUPT menyatakan bahwa direksi dalam mengurus perseroan harus demi kepentingan dan sesuai dengan maksud serta tujuan perseroan.

3) Pasal 97 ayat (1) UUPT menyatkan bahwa direksi diwajibkan mempunyai itikad baik dan bertanggung jawab dalam pengurusan perseroan.

4) Pasal 102 UUPT meyatakan bahwa adanya perbuatan-perbuatan hukum tertentu yang harus mendapatkan persetujuan terlebih dahulu dari komisaris dan atau RUPS yang diatur dalam anggaran dasar perseroan.

Uraian di atas telah menjelaskan perbuatan hukum perseroan yang tidak sesuai dengan batasan kewenangan sehingga tanggung jawab direksi menjadi tidak terbatas ketika telah melewati batasan kewenangannya. Di sisi lain, bagi para pemegang saham terkait pertanggungjawaban menjadi tidak terbatas sesuai Pasal 3 ayat (2) UUPT. Pasal 3 ayat (2) UUPT menyatakan bahwa ketentuan pada Pasal 3 ayat (1) UUPT tidak berlaku jika:

1) Persyaratan perseroan sebagai badan hukum belum atau tidak terpenuhi.

2) Pemegang saham yang bersangkutan dengan itikad buruk telah memanfaatkan perseroan untuk kepentingan pribadi baik secara langsung maupun tidak liangsung.

\footnotetext{
${ }^{15}$ Ais Chatamarrasjid. Op. Cit., h. 71.

${ }^{16}$ Ibid., h. 75.

${ }^{17}$ R. Subekti dan R. Tjitrosudibio, Kitab Undang-undang Hukum Perdata (KUH Perdata), Pradnya Paramita, Jakarta, 2003, Pasal 1331.

${ }^{18}$ Pemerintah Indonesia, Undang-Undang Nomor 40 Tahun 2007 tentang Perseroan Terbatas, Lembaran RI Tahun 2007 No. 40, Sekretariat Negara, Jakarta, 2007.
} 
3) Pemegang saham yang bersangkutan terlibat dalam perbuatan melawan hukum yang dilakukan oleh perseroan terkait.

4) Pemegang saham melakukan tindakan melawan hukum menggunakan harta kekayaaan perseroar baik secara langsung atau tidak langsung yang mengakibatkan harta kekayaan perseroan menjadi tidak cukup untuk melunasi hutang perseroan terkait. ${ }^{19}$

c) Tanggung Jawab Direksi

Direksi pada prinsipnya bertanggung jawab tidak hanya sebatas segala tindakan dalam kapasitasnya sebagai individu pribadi. Di sisi lain, terkait beberapa hal tertentu dia juga bertanggung jawab atas segala tindakan dalam kapasitasnya sebagai direktur perseroan. Bahkan dalam kapasitasnya sebagai direktur perseroan dia juga bertanggung jawab tidak hanya atas tindakan pribadinya tetapi juga bertanggung jawab atas tindakan direktur lainya, meskipun perihal ini hanya terjadi dalam beberapa kondisi tertentu yang berkaitan dengan direktur lainnya. Lebih lanjut, sampai pada batasan tertentu direksi bertanggung jawab juga atas tindakan pihak lain yang bukan dalam jajaran direktur. Perihal ini terjadi ketika tindakan tersebut dilakukan untuk dan atas nama perseroan terkait. $^{20}$

Ketentuan Undang-Undang Nomor 40 Tahun 2007 tentang Perseroan Terbatas terkait tindakan direksi sebagai tindakan perseroan menunjukan beberapa pengecualian. ${ }^{21}$ Meskipun segala tindakan direksi atas nama perseroan merupaka tindakan perseroan, tapi terdapat kemungkinan bahwa bukan perseroan terkait yang harus bertanggung jawab sebagai konsekuensi yuridis. Konsekuensi yuridis atau tanggung jawab juga dapat dibebankan kepada direksi secara pribadi atau secara tanggung jawab renteng. Oleh karena bentuk tanggung jawab direksi dibedakan menjadi tanggung jawab internal dan eksternal. Tanggung jawab internal meliputi tugas dan tanggung jawab direksi terhadap perseroan dan pemegang saham perseroan. Tanggung jawab eksternal berhubungan dengan tugas dan tanggung jawab direksi kepada pihak ketiga yang berhubungan hukum langsung atau tidak langsung dengan perseroan terkait. $^{22}$

\section{Keberadaan Prinsip Piercing The Corporate Veil pada Perseroan}

Tanggung jawab terbatas dari pemegang saham dapat dihapuskan atau dihilangkan dalam beberapa hal tertentu. Beberapa hal tertentu yang dimaksudkan yaitu: ${ }^{23}$

a) Persyaratan suatu perseroan terbatas sebagai sebuah badan hukum belum atau tidak terpenuhi.

b) Pemegang saham bersangkutan dalam perseroan terlibat dalam perbuatan melawan hukum yang dilakukan oleh atau atas nama perseroan terkait.

c) Secara langsung atau tidak langsung, pemegang saham pada perseroan dengan itikad buruk (taekwaadetrouw atau bad faith) memanfaatkan perseroan terkait hanya untuk kepentingan pribadi.

d) Secara langsung atau tidak langsung, pemegang saham pada perseroan melawan hukum yang berlaku menggunakan kekayaan perseroan yang berakibat harta kekayaan perseroan tidak cukup untuk melunasi hutang yang dimiliki oleh perseroan tersebut sesuai aturan Pasal 3 ayat (2) UUPT. ${ }^{24}$

pemegang saham dalam keadaan tertentu dapat kehilangan kekebalan atas pertanggungjawaban terbatasnya dan bertanggung jawab pribadi secara penuh. Keadaan tertentu dalam prinsip piercing the corporate veil yang terhadapnya dapat diterapkan yaitu:

a) Penggunaan harta kekayaan perseroan secara pribadi

b) Permodalan perseroan yang tidak layak

c) Formalitas eksistensi perseroan yag tidak ada

d) Terdapat unsur-unsur penipuan seperti menyalahgunakan badan hukum untuk kepentingan pribadi. ${ }^{25}$

Munir Fuady menyatakan bahwa terdapat beberapa fakta lain berdasarkan uraian di atas yang dapat digunakan sebagai alasan penerapan prinsip piercing the corporate veil terhadap perseroan induk, yaitu:

a) Anak perseroan memiliki modal sangat kecil dan tidak sebanding dengan modal yang dibutuhkan dalam melakukan kegiatan usaha.

b) Perseroan induk mempunyai seluruh atau sebagian besar saham pada anak perseroannya.

c) Perseroan induk melakukan tindakan pembiayaan menyeluruh terhadap anak perseroannya.

d) Semua kegiatan bisnis anak perseroan hanya pada perseroan induk.

\footnotetext{
${ }^{19}$ Pemerintah Indonesia, Undang-Undang Nomor 40 Tahun 2007 tentang Perseroan Terbatas, Lembaran RI Tahun 2007 No. 40, Sekretariat Negara, Jakarta, 2007, Pasal 3 ayat (2).

${ }^{20}$ Munir Fuady. 2002. Op. Cit., h. 72.

${ }^{21}$ Pemerintah Indonesia, Undang-Undang Nomor 40 Tahun 2007 tentang Perseroan Terbatas, Lembaran RI Tahun 2007 No. 40, Sekretariat Negara, Jakarta, 2007.

${ }^{22}$ Ahmad Yani dan Gunawan Widjaja. Op. Cit., h. 112.

${ }^{23}$ I.G. Ray Widjaja, Hukum perusahaan. Megapoin, Jakarta, 2000, h. 145.

${ }^{24}$ Pemerintah Indonesia, Undang-Undang Nomor 40 Tahun 2007 tentang Perseroan Terbatas, Lembaran RI Tahun 2007 No. 40 , Sekretariat Negara, Jakarta, 2007, Pasal 3 ayat (2).

${ }^{25}$ Munir Fuady. Op. Cit., h. 61-62.
} 
e) Aset anak perseroan digunakan oleh perseroan induk seakan-akan aset tersebut adalah miliknya sendiri.

f) Perseroan induk dan anak perseroan memiliki komisaris, direksi, dan pegawai pengurus perseroan yang sama.

g) Perseroan induk membayar keseluruhan gaji karyawan, kerugian, dan pengeluaran lainnya dari anak perseroannya.

h) Ketika anak perseroan tidak memiliki aset lain kecuali aset yang dialihkan dari perseroan induk.

i) Ketika pihak eksekutif pada anak perseroan lebih memprioritaskan kepentingan perseroan induk dari pada kepentinga perseroannya sendiri. Perihal ini menunjukan adanya ketimpangan prioritas kepentingan dalam perseroan tersebut.

Penerapan prinsip piercing the corporate veil secara khusus dalam sebuah perseroan pada dasarnya tidak hanya sebatas kepada perseroan induk. Prinsip piercing the corporate veil secara khusus juga dapat diterapkan kepada para pemegang saham di perseroan. Penerapan prinsip piercing the corporate veil kepada para pemegang saham dapat dilakukan pada empat kriteria, yaitu: ${ }^{26}$

a) Prinsip piercing the corporate veil terhadap badan hukum yang terpisah secara artifisial

b) Prinsip piercing the corporate veil berdasarkan hubungan kontrak

c) Perseroan dalam sudut pandang prinsip piercing the corporate veil tidak mengikuti formalitas tertentu.

d) Prinsip piercing the corporate veil ketika terjadi perbuatan melawan hukum.

e) Prinsip piercing the corporate veil dalam hubungan perseroan induk dan anak perseroan.

Berdasarkan analisis di atas menunjukan bahwa perseroan sebagai suatu badan hukum tidak berbeda dengan manusia. Perihal ini dikarenakan badan hukum mempunyai kehendak yang dibentuk melalui alat-alat perlengkapannya seperti Rapat Umum Pemegang Saham (RUPS), Direksi, dan Komisaris. Lebih lanjut, perseroan sebagai sebuah badan hukum merupakan suatu subyek hukum yang secara hukum memegang hak dan kewajiban. Perseroan sebagai sebuah usaha yang merupakan suatu badan hukum mempunyai hak dan kewajiban serta kapasitas untuk bertindak dalam hukum, sehingga berdasarkan perspektif subyek hukum badan usaha diketahui bahwa perseroan merupakan subyek hukum yang dapat diproses oleh hukum yang berlaku.

\section{B. Prinsip Piercing The Corporate Veil pada Undang-Undang Nomor 40 Tahun 2007 tentang Perseroan Terbatas}

\section{Penerapan Prinsip Piercing The Corporate Veil di Beberapa Negara}

Prinsip piercing the corporate veil pada dasarnya merupakan suatu prinsip yang berkembang dalam sistem hukum umum (common law). Walter Woon menyatakan bahwa terdapat dua hal yang mendasari hukum dalam penyingkapan tabir korporasi atau piercing the corporate veil dalam tanggung jawab terbatas. Pertama, faktanya perseroan tidaklah sebuah entitas yang terpisah atau bukan sebuah badan hukum terpisah yang mandiri. Harta kekayaan dan kepentingan perseroan dengan harta serta kepentingan pendiri atau pemegang saham tidak terdapat pemisahan yang jelas. Kedua, penyalahgunaan perseroan untuk tujuan yang tidak baik dan bukan untuk kepentingan menguntungkan perseroan terkait. Hal ini mengakibatkan kegiatan perseroan tidak lagi untuk kepentingan perseroan melainkan untuk kepentingan individu tertentu dalam perseroan. ${ }^{27}$

Prinsip piecing the corporate veil dewasa ini telah diterapkan oleh beberapa negara yang menganut sistem hukum umum (common law). Berikut ini adalah penjabaran singkat terkait penerapan prinsip piercing the corporate veil pada negara Amerika Serikat, Belanda, Australia, dan Inggris.

\section{a. Amerika Serikat}

Amerika Serikat terkait penerapan prinsip piercing the corporate veil mempunyai ketentuan-ketentuan tegas. Ketentuan-ketentuan tersebut dimaksudkan memperjelas waktu dan dalam hal tertentu untuk prinsip piercing the corporate veil dapat diterapkan di Amerika. Rudhy Prasetya dalam bukunya yang berjudul Kedudukan Mandiri Perseroan Terbatas Disertau dengan Ulasan menurut Undang-Undang Nomor 1 Tahun 1995 menyataka bahwa di Amerika terdapat beberapa faktor untuk pengadilan dapat menerapkan prinsip piercing the corporate veil, yaitu: ${ }^{28}$

1) Kegagalan dalam melakukan observasi formalitas perseroan terkait perilaku dan dokumentasi.

2) Kegagalan dalam mempertahankan hubungan dengan pihak ketiga.

3) Kegagalan dalam pembayaran terkait pembagian laba kepada para pemegang saham berdasarkan banyaknya saham yang dimiliki.

4) ketika adanya peleburan atau pencampuran aset perseroan dengan para pemegang saham.

5) Terjadi manipulasi aset perseroan atau pemusatan aset dan tanggung jawab.

6) Ketika terjadi penyembunyian atau salah representasi pemegang saham perseroan.

7) Ketiadaan atau ketidakakuratan catatan perseroan.

8) Tidak berfungsinya direksi atau petugas perseroan.

9) Kekurangan modal (kapitalisasi) yang signifikan dari perseroan. Kapitalisasi bervariasi berdasarkan industri, lokasi, dan keadaan spesifik perseroan.

\footnotetext{
${ }^{26}$ Ibid.

${ }^{27}$ Ibid., h. 40.

${ }^{28}$ Rudhy Prasetya, Kedudukan Mandiri Perseroan Terbatas Disertai dengan Ulasan menurut Undang-Undangah Nomor 1 Tahun 1995, Citra Aditya Bakti, Bandung, h. 230.
} 
10) Terjadinya penyaluran harta kekayaan perseroan oleh para pemegang saham mayoritas.

11) Perlakuan pemegang saham perseroan terhadap harta kekayaan perseroan seakan-akan harta kekayaan pribadi miliknya.

12) Ketika Perseroan digunakan sebagai sebuah tabir oleh pemegang saham mayoritas dalam dalam bisnis pribadinya.

13) Faktor relevan lain yang ditemukan oleh pengadilan.

Faktor-faktor di atas tidaklah harus semuanya terjadi (kumulatif) untuk pengadilan menerapkan prinsip piercing the corporate veil. Pada proses pengadilan dapat diterapkan prinsip piercing the corporate veil dengan salah satu faktor saja dan membuat para pemegang saham perseroan bertanggungjawab secara pribadi.

b. Belanda

Rudhy Prasetya menyatakan dalam Undang-undang Belanda prinsip piercing the corporate veil dapat diterapkan dalam beberapa kondisi, yaitu: ${ }^{29}$

1) Ketika suatu badan hukum jatuh pailit dan harta kekayaan badan hukum tersebut tidak cukup untuk melunasi hutang-hutangnya.

2) Ketika para pengurus suatu badan hukum secara nyata tidak melaksanakan tugasnya sebagaimana mestinya yang telah diatur dalam ketentuan-ketentuan sesuai anggaran dasar.

3) Ketika dapat diperkirakan terkait penyebab utama dari kepailitan suatu badan hukum dikarenakan oleh para pengurus dalam menjalankan tugas-tugasnya.

Berdasarkan penjabaran di atas menunjukan bahwa pengurus dapat dituntut untuk bertanggungjawab secara pribadi ketika memenuhi kondisi yang telah ditentukan. Pertangungjawaban pengurus secara pribadi dapat diartikan sebagai tanggung jawab secara pribadi atas sisa hutang yang masih belum terbayarkan dari badan hukum terkait. Perihal ini terjadi ketika harta kekayaan badan hukum tersebut tidak cukup untuk melunasi hutangnya. Pertanggung jawaban pribadi dalam hal ini tidak hanya sebatas pada arti formal di atas kertas menurut statua atau akta. Lebih lanjut, para pengurus di sini harus ditafsirkan termasuk orang-orang yang pada kenyataannya ikut menentukan dalam pengambilan keputusan dan kebijaksanaan persroan bersangkutan. Hal ini merujuk pada komisaris atau para pemegang saham.

c. Australia

Pengadilan Australia terkait prinsip piercing the corporate veil telah mengkonfirmasi lima persoalan seabagai syarat penerapannya, yaitu: ${ }^{30}$

1) Ketika terjadi tindakan kecurangan (fraud) dengan perusahaan digunakan pihak yang mengontrol untuk melakukan kecurangan.

2) Persoalan keagenan (agency atau alter ego) yaitu ketika dalam tingkatan tertentu, pemegang saham secara efektif mengontrol perseroan yang membuat tindakan pemegang saham tersebut seperti tindakan oleh perseroan.

3) Tindakan pemalsuan (sham atau façade) yaitu perseroan digunakan pihak pengontrol sebagai topeng (mask) untuk mencapai tujuan tertentu, pada umumnya bersifat ilegal.

4) Persoalan dalam kelompok usaha pada keadaan tertentu dioperasikan dengan cara yang dapat membuat anggota usaha tidak bisa dibedakan. Contohnya ketika terdapat tumpang tindih direksi, pejabat atau pekerja, dan ketika keadaan kerja sama antara perseroan dalam sebuah kelompok usaha maupun kepemilikan bersama. Perihal ini menjadikan perseroan induk dimintai pertanggungjawaban.

5) Persoalan ketidakjujuran (unfairness) yaitu sebuah usaha untuk mendapatkan keadilan (justice) yang membuat prisip piercing the corporate veil dapat diterapkan. Penerapan prinsip piercing the corporate veil dimaksudkan untuk mendapatkan hasil yang lebih jujur dan adil atau untuk menghentikan keadan yang dapan menghasilkan ketidakjujuran.

Berdasarkan syarat penerapan prinsip piercing the corporate veil di atas, pengadilan dapat mengangkat tabir perlindungan (corporate veil) bagi direksi dan pemegang saham perseroan di Australia. Kondisi ini dapat terjadi jika pemegang saham secara dominan menggunakan posisinya atas perseroan untuk kepentingan ilegal atau kejahatan. Lebih lanjut, prinsip piercing the corporate veil juga dapat diterapkan ketikadireksi yang bertindak curang, tidak jujur, atau melakukan tindakan kejahatan termasuk jika perseroan bersangkutan hanyalah sebuah kedok palsu.

d. Inggris

penyebab penerapan prinsip piercing the corporate veil untuk menghapus tabir yang melindungi pemegang saham oleh pengadilan di Inggris yaitu: ${ }^{31}$

1) Pemegang saham pengendali (controlling shareholders) menggunakan perseroan untuk mencapai tujuan yang ilegal (illegal purpose) dan tujuan tidak tepat (improper purpose).

\footnotetext{
${ }^{29} \mathrm{Ibid} .$, h. 229.

${ }^{30} I b i d .$, h. 257-268.

${ }^{31}$ Ibid., h. 527.
} 
2) Perseroan didirikan oleh pemegang saham sebagai upaya untuk menghindari suatu tanggung jawab hukum.

3) Jaringan perseroan atau perwalian (termasuk di luar negeri) digunakan sebagai upaya untuk menyembunyikan hasil yang diperoleh dari suatu tindakan kejahatan.

4) Pemegang saham mempunyai keinginan untuk melepaskan saham, kepentingan atau aset di lembaga perwalian atau perseroan yang bertentangan dengan hukum sehingga dilarang pengadilan.

5) Perusahaan digunakan sebagai upaya untuk menghindari kewajiban membayar manajer yang dipecat.

6) Sehubungan dengan gugatan atas kerugian yang timbul dari penggunaan dana perseroan oleh pemegang saham secara individu dalam upayanya untuk memperoleh kendali atas perseroan publik.

Pemaparan di atas menunjukan bahwa perlindungan terhadap pemegang saham perseroan (corporate veil) di Inggris dapat diangkat. Perihal ini dapat terjadi ketika pemegang saham pengendali secara salah telah menggunakan posisinya. Pemegang saham tersebut telah menggunakan perseroan untuk kepentingan ilegal atau kejahatan, dan ketika ada tindakan pendirian serta pengelolaan perseroan palsu dengan tujuan untuk melakukan tindak kecurangan atau kejahatan.

Berdasarkan pemaparan di atas terkait penerapan prinsip piercing the corporate veil di negara Amerika Serikat, Belanda, Australia, dan Ingrris menunjukan bahwa perseroan sebagai suatu badan hukum tidak berbeda dengan manusia. Perihal ini dikarenakan badan hukum mempunyai kehendak yang dibentuk melalui alat-alat perlengkapannya seperti Rapat Umum Pemegang Saham (RUPS), Direksi, dan Komisaris. Lebih lanjut, perseroan sebagai sebuah badan hukum merupakan suatu subyek hukum yang secara hukum memegang hak dan kewajiban. Perseroan sebagai sebuah usaha yang merupakan suatu badan hukum mempunyai hak dan kewajiban serta kapasitas untuk bertindak dalam hukum, sehingga berdasarkan perspektif subyek hukum badan usaha diketahui bahwa perseroan merupakan subyek hukum yang dapat diproses oleh hukum yang berlaku melalui penerapan prinsip piercing the corporate veil.

2. Penerapan Prinsip Piercing The Corporate Veil pada Undang-Undang Nomor 40 Tahun 2007 tentang Perseroan Terbatas

Prinsip piercing the corporate veil sendiri mempunyai kriteria untuk diterapkan di Indonesia yang telah diatur dalam beberapa pasal dalam Undang-undang Nomor 40 tahun 2007 tentang Perseroan Terbatas.

a. Pasal 3 ayat (2), Pasal 7 ayat (6), Pasal 12, Pasal 13 UUPT.

Pasal 3 ayat (2) UUPT mengatur tentang ketentuan pemegang saham perseroan yang harus bertanggung jawab sampai pada harta kekayaan pribadi mereka. Perihal ini dapat terjadi jika pihak bersangkutan melakukan tindakan melanggar hukum. Bentuk tanggung jawab pemegang saham sampai pada harta kekayaan pribadi dalam UUPT juga diatur ketika melakukan pelanggaran terhadap Pasal 7 ayat (6), Pasal 12, dan Pasal 13 UUPT, yaitu: ${ }^{32}$

1) Tidak atau belum terpenuhinya persyaratan perseroan sebagai sebuah badan hukum.

2) Secara langsung ataupun tidak langsung, pemegang saham yang bersangkutan dengan itikad buruk memanfaatkan perseroan untuk tujuan pribadinya.

3) Pemegang saham yang bersangkutan terlibat dalam tindakan melawan hukum yang dilakukan atas nama perseroannya.

4) Secara langsung atau tidak langsung, pemegang saham yang bersangkutan bertindak melawan hukum menggunakan harta kekayaan perseroan dan mengakibatkan harta kekayaan perseroan terkait tidak cukup untuk melunasi hutang-hutangnya.

5) Setelah pengesahan perseroan oleh pemegang saham kurang dari dua orang dan dalam waktu enam bulan setelahnya jumlah pemegang saham tetap dua orang tersebut, maka pemegang saham ini secara pribadi bertangung jawab atas segala perikatan, kerugian perseroan, dan atas permohonan pihak yang berkepentingan. Perihal ini dapat membuat Pengadilan Negeri membubarkan perseroan tersebut.

6) Tindakan hukum pendiri perseroanuntuk kepentingan perseroan yang mana perseroan bersangkutan belum berstatus sebagai badan hukum, tetapi tindakan hukum tersebut oleh perseroan:

a) Tidak menyatakan secara tegas bahwa semua perjanjian yang dibuat diterima oleh pendiri atau pihak lain yang ditugaskan pendiri perseroan dengan pihak ketiga.

b) Tidak menyatakan mengambil alih semua hak dan kewajiban yang muncul sebagai akibat dari perjanjian penidiri atau pihak lain yang ditugaskan pendiri, meskipun perjanjian tidak mengatasnamakan perseroan.

c) Tidak adanya catatan pengukuhan secara tertulis terkait semua tindakan hukum yang dilakukan atas nama perseroan.

Perseroan mempunyai wewenang untuk mengukuhkan setiap tindakan hukum tersebut dalam RUPS. Jika RUPS tidak dapat diselenggarakan, maka pengukuhan dapat dilakukan olah seluruh pendiri, pemegang saham, dan direksi perseroan. Ketika pengukuhan belum dilakukan dengan alasan perseroan tidak jadi untuk didirikan atau perseroan tidak melakukan pengukuhan, maka pereroan dapat dinyatakan tidak terikat.

\footnotetext{
${ }^{32}$ Pemerintah Indonesia, Undang-Undang Nomor 40 Tahun 2007 tentang Perseroan Terbatas, Lembaran RI Tahun 2007 No. 40, Sekretariat Negara, Jakarta,
} 2007, Pasal ayat (3), Pasal 12, dan Pasal 13. 
b. Pasal 14 UUPT

Direksi perseroan tidak melakukan perosedur hukum yang berlaku dalam perundang-undangan ketika proses pendirian perseroan. Hal ini menunjukan direksi perseroan tidaklah melakukan permintaan pengesahan, persertujuan, pelaporan, pendaftaran, dan pengumuman sebagaimana yang telah diatur dalam Pasal 14 UUPT. $^{33}$

c. Pasal 37 ayat (2) dan (3)

Perolehan saham yang tidak sesuai dengan ketentuan dalam Pasal 37 ayat (3) yang menyatakan bahwa direksi perseroan secara tanggung jawab renteng bertanggung jawab atas semua kerugian pemegang saham yang bertindak dengan itikan baik. Kerugian ini timbul akibat batal demi hukum sesuai dengan ketentuan Pasal 37 ayat $(2) .^{34}$

d. Pasal 69 ayat (3)

Ketika dokumen perhitungan tahunan yang disediakan tidak benar sebagaimana ketentuan pdalam pasal 69 ayat (3). Pasal 69 ayat (3) UUPT menyatakan bahwa dalam hal dokumen perhitungan tahunan yang disediakan ternyata tidak benar dan atau menyesatkan, maka direksi dan komisaris secara tanggung renteng bertanggung jawab terhadap pihak yang dirugikan. ${ }^{35}$

e. Pasal 97 ayat (2) dan (3)

Ketika direksi tidak melaksanakan fiduciary duty yang diberikan oleh perseroan sesuai ketentuan Pasal 97 ayat (2) UUPT. Pada pasal tersebut menyatakan bahwa pengurusan sebagaimana yang dimaksus pada ayat (1) wajib untuk dilaksanakan setiap anggota direksi dengan itikad baik dan penuh tanggung jawab. Lebih lanjut, pada Pasal 97 ayat (3) menambahkan bahwa setiap anggota dureksi bertanggung jawab penuh secara pribadi atas kerugian perseroan jika yang bersangkutan bersalah atau lalai dalam menjalankan tugasnya. ${ }^{36}$

f. Pasal 104 ayat (2)

Ketika terjadi kepailitan yang disebabkan kesalahan direksi telah diatur pada Pasal 104 ayat (2) UUPT. ${ }^{37}$ Pasal tersebut menyatakan bahwa dalam hal kepailitan terjadi karena kesalahan atau kelalaian direksi dan harta kekayaan perseroan tidak cukup untuk menutup kerugian yang ditimbulkan, maka setiap anggota direksi secara tanggung renteng bertanggung jawab atas kerugian tersebut.

g. Pasal 114 ayat (2)

Ketika komisaris perseroan telah melanggar ketentuan Pasal 114 ayat (2) UUPT. ${ }^{38}$ Pasal tersebut menyatakan bahwa komisaris perseroan tidak mempunyai itikad baik, tidak berhati-hati, dan tidak bertangung jawab dalam menjalankan tugas pengawasan serta pemberian nasehat kepada direksi.

Pada UUPT terkait penerapan kondisi ini dirasa sangat sulit untuk diungkap karena Indonesia menganut hukum kontinental. Berdasarkan hukum kontinental menunjukan penegakannya lebih condong kepada positifisme hukum. Di sisi lain, pada prinsip piercing the corporate veil menganut hukum anglo saxon. UUPT sampai pada batas-batas tertentu mengakui pemberlakuan prinsip piercing the corporate veil walaupun bentuk pengaturannya dirasa sangat sederhana. Penerapan prinsip piercing the corporate veil dalam tindakan perseroan menyebabkan tanggung jawab hukum tidak hanya dimntakan pada perseroan bersangkutan (walaupun berbentuk badan hukum). Permintaan tanggung jawab hukum ini juga dapat ditujukan langsung terhadap para pemegang saham perseroan. Munir Fuady terkait penerapan prinsip piercing the corporate veil menyatakan bahwa dalam perkembangannya juga membebankan tanggung jawab hukum kepada organ perseroan lain. ${ }^{39}$ Organ perseroan lain yang dimaksud adalah direksi dan komisaris. Perihal ini membuat Undang-undang Nomor 40 tahun 2007 tentang Perseroan Terbatas mengakui keberadaan prinsip piercing the corporate veil dengan membagi beban tanggung jawab kepada beberapa pihak. Pertama, beban tanggung jawab dipindahkan kepada pihak komisaris. Kedua, beban tanggung jawab dipindahkan kepada pihak direksi. Ketiga, beban tanggung jawab dipindahkan kepada pihak pemegang saham. ${ }^{40}$

Berdasarkan pemaparan analisis di atas menunjukan bahwa ketentuan peraturan perundang-undangan yang berlaku dan mengikat kepada perseroan di Indonesia adalah Undang-undang Nomor 40 Tahun 2007 tentang Perseroan terbatas. UUPT sebagai peraturan hukum nasional Indonesia dapat dijadikan sebagai payung hukum bagi perseroan.

${ }^{33}$ Pemerintah Indonesia, Undang-Undang Nomor 40 Tahun 2007 tentang Perseroan Terbatas, Lembaran RI Tahun 2007 No. 40 , Sekretariat Negara, Jakarta, 2007, Pasal 14.

${ }^{34}$ Pemerintah Indonesia, Undang-Undang Nomor 40 Tahun 2007 tentang Perseroan Terbatas, Lembaran RI Tahun 2007 No. 40 , Sekretariat Negara, Jakarta, 2007, Pasal 37 ayat (2) dan (3).

${ }^{35}$ Pemerintah Indonesia, Undang-Undang Nomor 40 Tahun 2007 tentang Perseroan Terbatas, Lembaran RI Tahun 2007 No. 40 , Sekretariat Negara, Jakarta, 2007, Pasal 69 ayat (3).

${ }^{36}$ Pemerintah Indonesia, Undang-Undang Nomor 40 Tahun 2007 tentang Perseroan Terbatas, Lembaran RI Tahun 2007 No. 40 , Sekretariat Negara, Jakarta, 2007, Pasal 97 ayat (2) dan (3).

${ }^{37}$ Pemerintah Indonesia, Undang-Undang Nomor 40 Tahun 2007 tentang Perseroan Terbatas, Lembaran RI Tahun 2007 No. 40 , Sekretariat Negara, Jakarta, 2007, Pasal 104 ayat (2).

${ }^{38}$ Pemerintah Indonesia, Undang-Undang Nomor 40 Tahun 2007 tentang Perseroan Terbatas, Lembaran RI Tahun 2007 No. 40 , Sekretariat Negara, Jakarta, 2007, Pasal 114 ayat (2).

${ }^{39}$ Ibid., h. 17.

${ }^{40}$ Pemerintah Indonesia, Undang-Undang Nomor 40 Tahun 2007 tentang Perseroan Terbatas, Lembaran RI Tahun 2007 No. 40 , Sekretariat Negara, Jakarta, 2007. 
Penggunaan sebagai payung hukum ini disesesuaikan dengan tingkat, derajat, dan peraturan hukum itu sendiri terkait daya ikat terhadap materi-materi yang dimuat dalam peraturan hukum tersebut. Perihal ini disebut sebagai konsep keadilan dan legalitas. Konsep keadilan dan legalitas tersebut diterapkan melalui Undang-undang Nomor 40 Tahun 2007 tentang Perseroan Terbatas sebagai penerapan prinsip piercing the corporate veil pada perseroan di Indonesia.

\section{IV.KESIMPULAN}

Perseroan sebagai suatu badan hukum tidak berbeda dengan manusia. Perihal ini dikarenakan badan hukum mempunyai kehendak yang dibentuk melalui alat-alat perlengkapannya seperti Rapat Umum Pemegang Saham (RUPS), Direksi, dan Komisaris. Lebih lanjut, perseroan sebagai sebuah badan hukum merupakan suatu subyek hukum yang secara hukum memegang hak dan kewajiban. Perseroan sebagai sebuah usaha yang merupakan suatu badan hukum mempunyai hak dan kewajiban serta kapasitas untuk bertindak dalam hukum, sehingga berdasarkan perspektif subyek hukum badan usaha diketahui bahwa perseroan merupakan subyek hukum yang dapat diproses oleh hukum yang berlaku.

Prinsip piercing the corporate veil diadopsi ke dalam hukum perseroan dengan tujuan untuk menghindari ketidakadilan atas tindakan sewenang-wenang atau tidak layak yang dilakukan dengan mengatasnamakan perseroan, baik yang terbit dari suatu transaksi dengan pihak ketiga maupun yang muncul atas perbuatan menyesatkan dan perbuatan melawan hukum. Undangundang Nomor 40 tahun 2007 tentang Perseroan Terbatas sebagai ketentuan peraturan perundang-undangan yang berlaku dan mengikat kepada perseroan di Indonesia mennunjukan bahwa sampai pada batas-batas tertentu mengakui berlakunya prinsip piercing the corporate veil. . UUPT sebagai peraturan hukum nasional Indonesia dapat dijadikan sebagai payung hukum bagi perseroan. Penggunaan sebagai payung hukum ini disesesuaikan dengan tingkat, derajat, dan peraturan hukum itu sendiri terkait daya ikat terhadap materi-materi yang dimuat dalam peraturan hukum tersebut. Perihal ini disebut sebagai konsep keadilan dan legalitas. Konsep keadilan dan legalitas tersebut diterapkan melalui Undang-undang Nomor 40 Tahun 2007 tentang Perseroan Terbatas sebagai penerapan prinsip piercing the corporate veil pada perseroan di Indonesia.

\section{DAFTAR PUSTAKA}

Agung, I. (2010). Perspektif Multidimensional Pendidikan Pembangunan Berkelanjutan: Pemikiran Awal Konsep dan Penerapan. Jurnal Pendidikan dan Kebudayaan, 16(4), 453-468.

Asshiddiqie, Jimly dan Ali safa'at, Teori Hans Kelsen tentang Hukum, Konstitusi Press, Jakarta, 2006.

Chatamarrasjid, Ais, Penerobosan Cadar Perseroan dan Soal-soal Aktual Hukum Perusahaan, Citra Aditya Bakti, Bandung, 2004.

Departemen Pendidikan dan Kebudayaan, Kamus Besar Bahasa Indonesia. Balai Pustaka, Jakarta.

Dewi, Subjek dan Objek Hukum, diakses dari Wordpress: https://dewimanroe.wordpress.com/2013/05/06/subjek-dan-objek-hukum/, dipetik 17 Mei 2020.

Fuady, Munir, Hukum Perusahaan Dalam Paradigma Hukum Bisnis, Citra Aditya Bakti, Bandung, 2002.

------, Doktrin-doktrin Modern Dalam Corporate Law dan Eksistensinya Dalam Hukum Indonesia. Citra Aditya Bakti, Bandung, 2002.

G., Thomas Heinztman. dan Brandon Kain, Through the Looking Glass: Recent Developments in Piercing the Corporate Veil, Cavendish Publishing, London, 2013.

Gierke, Otto Van dalam Ali Ridho, Badan Hukum dan Kedudukan Badan Hukum Perseroan, Perkumpulan, Koperasi, Yayasan, Wakaf, Alumni, Bandung, 1993. Goulding, Simon, Company Law, Edisi Kedua, Cavendish Publishing Limited, London, 1999.

Halim, Ridwan, Hukum Perdata Dalam Tanya Jawab, Cetakan Kedua, Ghalia Indonesia, Jakarta, 1985.

Harahap, Yahya, Hukum Perseroan Terbatas, Sinar Grafika, Jakarta, 2009

Hutabarat, Benny Batara Tumpal, Penerapan Prinsip Piercing The Corporate Veil Terhadap Pemegang Saham Selaku Personil Pengendali Korporasi Dalam Tindak Pidana Pencucian Uang Oleh Perseroan Terbatas, Universitas Indonesia, Depok, 2011.

Kasim, Umar, Tanggung Jawab Korporasi Dalam Hal Mengalami Kerugian, Kepailitan atau Likuidasi, Jurnal Informasi Hukum Vol. 2 Tahun 2005, diakses .dari http://www.nakertrans.go.id/majalah_buletin/info_hukum/vol2vii005/TanggungjawabKorporasi.php, dipetik 29 Maret 2020.

Kelsen, Hans, General Theory of Law and State, diterjemahkan oleh Rasisul Muttaqien, Nusa Media, Bandung, 2011.

Manurung, Andy, Pengaruh With Holding Tax System Terhadap Optimalisasi Penerimaan Pajak Penghasilan, dari: http://andymanurung.blogspot.co.id/, dipetik 24 Mei 2020.

Marzuki, Peter Mahmud, Penelitian Hukum, Kencana Prenada Media Group, Jakarta, 2016.

Masyhur, Kahar, Membina Moral dan Akhlak, Kalan Mulia, Jakarta, 1985.

Notaris dan PPAT, Dasar hukum Perseroan Terbatas yang ada diIndonesia, diakses dari: http://www.notarisdanppat.com/dasar-hukum-untuk-perseroanterbatas-yang-ada-di-indonesia/, dipetik 16 Mei 2020.

Pemerintah Australia, The Australian Corporation Act, Australia, 2001.

Pemerintah Indonesia, Undang-Undang Nomor 40 Tahun 2007 tentang Perseroan Terbatas, Lembaran RI Tahun 2007 No. 40 , Sekretariat Negara, Jakarta, 2007.

Pemerintah Inggris, U.K. Companies Act 2006, Inggris, 2006.

Prasetya, Rudhy, Kedudukan Mandiri Perseroan Terbatas Disertai dengan Ulasan menurut Undang-Undangah Nomor 1 Tahun 1995, Citra Aditya Bakti, Bandung.

Ramsey, Ian M. dan David B. Noakes, Piercing The Corporate Veil in Australia, Jurnal perusahaan dan hukum keaamanan, 2001.

Sagala, Ronald U. P., Tanggung Jawab Terbatas Pemegang Saham Menurut Undang-Undang Perseroan Terbatas, Universitas Indonesia, Jakarta, 2010.

Shidarta, Perlindungan Konsumen, Grasindo, Jakarta.

Sirait, Ningrum N., Modul Hukum Perusahaan. Program Studi Magister Ilmu Hukum, USU, Medan, 2006.

Sjahdeini, Remy Sutan, Hukum Kepailitan, Pustaka Utama Grafiti, Jakarta, 2002.

Soekanto, Soerjono, Pengantar Penelitian Hukum, Kencana Prenada Media, Jakarta, 2008

Subekti, R. dan R. Tjitrosudibio, Kitab Undang-undang Hukum Perdata (KUH Perdata), Pradnya Paramita, Jakarta, 2003.

Syafi'i, Muhammad, Piercing The Corporate Veil Terhadap Holding Company Dalam Tindakan Hukum Anak Perusahaan, Universitas Muhammadiyah, Yogyakarta.

------, Tinjauan Umum Tanggung Jawab Hukum Rumah Sakit Sebagai Pelaku Usaha, dari Repository USU: http://repository.usu.ac.id/bitstream/123456789/37833/3/Chapter\%20II.pdf, dipetik 14 Mei 2020.

Usman, Rachmadi, Dimensi Hukum Perusahaan Perseroan Terbatas, PT. Alumni, Bandung, 2004. 
Website : http://yustisia.unmermadiun.ac.id/index.php/yustisia

Widiyono, Tri, Direksi Perseroan Terbatas (Bank Perseroan) Keberadaan, Tugas, Wewenang dan Tanggung Jawab, Berdasarkan Doktrin Hukum dan UUPT, Ghalia Indonesia, Jakarta, 2005.

Widjaja, Gunawan, Tanggung Jawab Direksi atas Kepailitan Perseroan, Raja Grafindo Persada, Jakarta, 2004.

Widjaja, I.G. Ray, Hukum perusahaan. Megapoin, Jakarta, 2000.

Yani, Ahmad dan Gunawan Widjaja, Seri Hukum Bisnis Perseroan Terbatas, Raja Grafindo Persada, Jakarta, 2003. 